\title{
Analysis of cassava growth at different harvest times and planting densities
}

\section{Análise do crescimento de mandioca em diferentes épocas de colheita e densidades de plantio}

\author{
Eli Carlos de Oliveira' ${ }^{1 *}$; Luiz Henrique Campos de Almeida ${ }^{2}$; Claudemir Zucareli; \\ Teresa Losada Valle ${ }^{4}$; José Roberto Pinto de Souza ${ }^{3}$; Édison Miglioranza ${ }^{3}$
}

\begin{abstract}
Vegetative canopy architecture, and plant population density, has a direct influence on the growth and production of crops. The objective of this study was to evaluate the growth of four cassava cultivars of contrasting canopies, in four population densities, during two vegetative cycles. A randomized complete block design was used in a subdivided plot scheme, with two replications, with the population densities in the plots and harvesting times in the subplots. 'Branca de Santa Catarina' (BSC), 'IAC 13', 'IAC 1418 ' and 'Fibra' were collected every four months, beginning at 120 and ending at 720 days after planting (DAP). Primary data on dry matter and leaf area were calculated. The total dry mass $\left(\mathrm{W}_{\mathrm{t}}\right)$, leaf area ratio $\left(\mathrm{L}_{\mathrm{a}}\right)$, leaf area index $(\mathrm{L})$, relative growth rate $\left(\mathrm{R}_{\mathrm{w}}\right)$, and net assimilation rate $\left(\mathrm{E}_{\mathrm{a}}\right)$ were calculated based on the primary data. All cultivars accumulated more total dry mass $\left(\mathrm{W}_{t}\right)$ at lower planting densities. The plants reached a higher leaf area ratio $\left(\mathrm{L}_{\mathrm{a}}\right) 120$ days after planting. In the second vegetative cycle, the four cultivars, independently of the population, presented a reduction of assimilate translocation to the leaves. Relative growth rate $\left(\mathrm{R}_{\mathrm{w}}\right)$ of the cultivars varied strongly with the plant population only in the second cycle. 'IAC 14-18' showed greater dependence on spacing, and 'Fibra' less dependence. Growth $\left(\mathrm{R}_{\mathrm{w}}\right)$ and assimilatory $\left(\mathrm{E}_{\mathrm{a}}\right)$ rates decreased at the end of the first cycle, then increased slowly until the end of the second cycle of vegetation.
\end{abstract}

Key words: Manihot esculenta Crantz. Leaf area index. Dry mass. Net assimilation rate.

\section{Resumo}

A arquitetura do dossel vegetativo e a população das plantas têm influência direta no crescimento e na produção das culturas. O objetivo desta pesquisa foi avaliar o crescimento de quatro cultivares de mandioca de dosséis contrastantes em quatro densidades populacionais por dois ciclos vegetativos. Utilizou-se o delineamento em blocos casualizados no esquema de parcelas subdivididas, com duas repetições, sendo as densidades populacionais nas parcelas e épocas de colheita nas subparcelas. Foram estudadas 'Branca de Santa Catarina'(BSC), 'IAC 13', 'IAC 14-18'e 'Fibra' colhidas quadrimestralmente, com início aos 120 e finalizando aos 720 dias após o plantio (DAP). Foram determinados os dados primários massa seca e área foliar. A partir dos dados primários foi aplicada a análise de crescimento e calculada a massa seca total $\left(\mathrm{W}_{\mathrm{t}}\right)$, razão de área foliar $\left(\mathrm{F}_{\mathrm{a}}\right)$, índice de área foliar $(\mathrm{L})$, taxa de crescimento

${ }^{1}$ Eng $^{\circ}$ Agr $^{\circ}$, Dr. Pesquisador, Omnia Brasil, Leme, SP, Brasil. E-mail: elioliveira.agro@gmail.com

2 Eng $^{\circ}$ Agr $^{\circ}$, M.e, Discente do Curso de Doutorado em Fitotecnia, Universidade Estadual de Londrina, Centro de Ciências Agrárias, Departamento de Agronomia, UEL, Londrina, PR, Brasil. E-mail: caluizhenrique@msn.com

3 Eng ${ }^{\text {os }}$ Agr ${ }^{\text {os }}$, Profs. Drs., Departamento de Agronomia UEL/CCA, Londrina, PR, Brasil. E-mail: claudemircca@uel.br; jose@uel. br; emiglior@uel.br

4 Eng ${ }^{\text {a }}$ gra $^{\mathrm{a}}$, Instituto Agronômico de Campinas, IAC, Campinas, SP, Brasil. E-mail: teresalv@iac.sp.gov.br

* Author for correspondence 
relativo $\left(\mathrm{R}_{\mathrm{w}}\right)$ e a taxa assimilatória liquida $\left(\mathrm{E}_{\mathrm{a}}\right)$. Todas as cultivares acumularam mais massa seca $\left(\mathrm{W}_{\mathrm{t}}\right)$ nas menores densidades de plantio. As plantas atingiram maior razão de área foliar $\left(\mathrm{F}_{\mathrm{a}}\right)$ aos 120 dias após o plantio. No segundo ciclo vegetativo, as quatro cultivares, independentemente da população, apresentaram redução da translocação de assimilados para as folhas. As taxas de crescimento relativo $\left(\mathrm{R}_{\mathrm{w}}\right)$ das cultivares variaram de maneira mais acentuada com a população de plantas apenas no segundo ciclo. A 'IAC 14-18' apresentou maior dependência dos espaçamentos e 'Fibra' menor dependência. As taxas de crescimento $\left(\mathrm{R}_{\mathrm{w}}\right)$ e assimilatórias $\left(\mathrm{E}_{\mathrm{a}}\right)$ decrescem no final do primeiro ciclo, depois crescem lentamente até o final do segundo ciclo vegetativo.

Palavras-chave: Manihot esculenta Crantz. Índice de área foliar. Massa seca. Taxa assimilatória líquida.

\section{Introduction}

Cultivated mainly in tropical and subtropical regions, cassava (Manihot esculenta Crantz), is currently classified as the main food source for several countries located in these regions (FAO, 2014). Due to the high levels of carbohydrates in its tuberous roots, it guarantees the supply of about $60 \%$ of the daily caloric needs for populations of tropical Africa (HOWE et al., 2009; AKINWALE et al., 2010). In Brazil, cassava plays a relevant socioeconomic role in agribusiness, either through the consumption of "in natura" roots, or byproducts such as flours and starches (GAMEIRO, 2002). Thus, this plant has importance both for food security and for the development of industry and job creation.

Although the species presents high edaphoclimatic adaptability, its agronomic performance depends on several factors, such as planting time, plant population, quality of planting material, mineral nutrition, and herbicide application among others (VIDIGAL FILHO et al., 2000; AYOOLA, 2006; SCHONS et al., 2007; AYOOLA; MAKINDE, 2008; NTAWURUHUNGA; DIXON, 2010; FERREIRA et al., 2015).

Among the factors that influence productivity, planting density has a considerable influence on cassava growth and development and is closely correlated with the architecture of the aerial part (FERREIRA et al., 2015). The increase in the number of plants promotes competition, both between individuals of the same, and different species, for resources such as water, nutrients, $\mathrm{CO}_{2}$, and light, which may affect the final production of the tuberous roots. Aguiar et al. (2011), studying the effect of population density on sweet cassava production, observed an increase in the production of commercial roots with the reduction of plant densities, as well as increases in the diameter of these roots, which decreased discards.

The growth and development of cassava can be estimated using physiological indexes, in order to identify its practical value, besides expressing the morphophysiological conditions of the plants, and quantifying the net production resulting from the photosynthetic activity. According to Peixoto et al. (2012), physiological indexes provide insights into the adaptations experienced by plants under different environmental conditions: light, temperature, humidity, and soil fertility.

Growth measures are obtained according to Radford (1967), throughout the crop cycle, and can be analyzed mathematically or graphically. The regression equations allow correction of the normal oscillations, to estimate the growth tendency, and to evaluate pattern variations in plant growth, in relation to the height, dry mass matter, or leaf area, as a function of treatments or of genetic variability (BENINCASA, 2004).

Growth measures to monitor plant development over time, consist of relative growth rate $\left(\mathrm{R}_{\mathrm{w}}\right)$, net assimilation rate $\left(\mathrm{E}_{\mathrm{a}}\right)$, leaf area ratio $\left(\mathrm{L}_{\mathrm{a}}\right)$, and leaf area index (L) (PORTES; CASTRO JÚNIOR, 1991; HUNT et al., 2003; PEIXOTO; PEIXOTO, 2009).

Practical examples of the relationship between $\mathrm{R}_{\mathrm{w}}, \mathrm{L}_{\mathrm{a}}, \mathrm{L}$, and the density of cassava plants were 
verified by Gomes et al. (2007). The authors saw an increase of the biomass, per unit of biomass of plants in the lower population densities. $\mathrm{E}_{\mathrm{a}}$ was negatively correlated with the number of leaves per unit area in Machado et al. (1982). This is due to the foliar shading of plants with dense aerial part architecture, resulting in $\mathrm{E}_{\mathrm{a}}$ reduction during the growth and development of plants. Therefore, the objective of this study was to evaluate the growth and development of four cassava cultivars of different architectures, in different population densities, during two vegetative cycles.

\section{Material and Methods}

The experiment was conducted between 2014 and 2015 at the former Experimental Station of the Assis Agronomic Institute, currently Regional Pole of the Paranapanema of the Paulista Agency for Agribusiness Technology (Agência Paulista de Tecnologia dos Agronegócios - APTA), in the municipality of Assis - SP, (latitude $22^{\circ} 40^{\prime} \mathrm{S}$, longitude $50^{\circ} 26^{\prime} \mathrm{W}$ and average altitude of $563 \mathrm{~m}$ ). The soil of the region is characterized as Distroferric Dark Red Latosol, with a moderate A horizon, and medium sandy phase texture (EMBRAPA, 2013). The climate was classified as dry winter, and hot and humid (Cwa), according to the classification of Köppen. The climatic data recorded during the study are shown in Figure 1. Four cassava cultivars, 'Branca de Santa Catarina' (BSC), 'IAC 13', 'IAC 14-18' and 'Fibra' were used. These cultivars were chosen due to their different canopy architectures; 'BSC' shows open branching plants, 'IAC 13' has vigorous stems and closed branches, 'IAC 14-18' has closed branches, and 'Fibra' are plants with no branching. Planting was carried out in four planting densities for each cultivar, adopting spacing recommendations as criteria, according to their architecture (Table 1).

Figure 1. Average precipitation, and maximum and minimum temperatures during the experiment in Assis - SP.

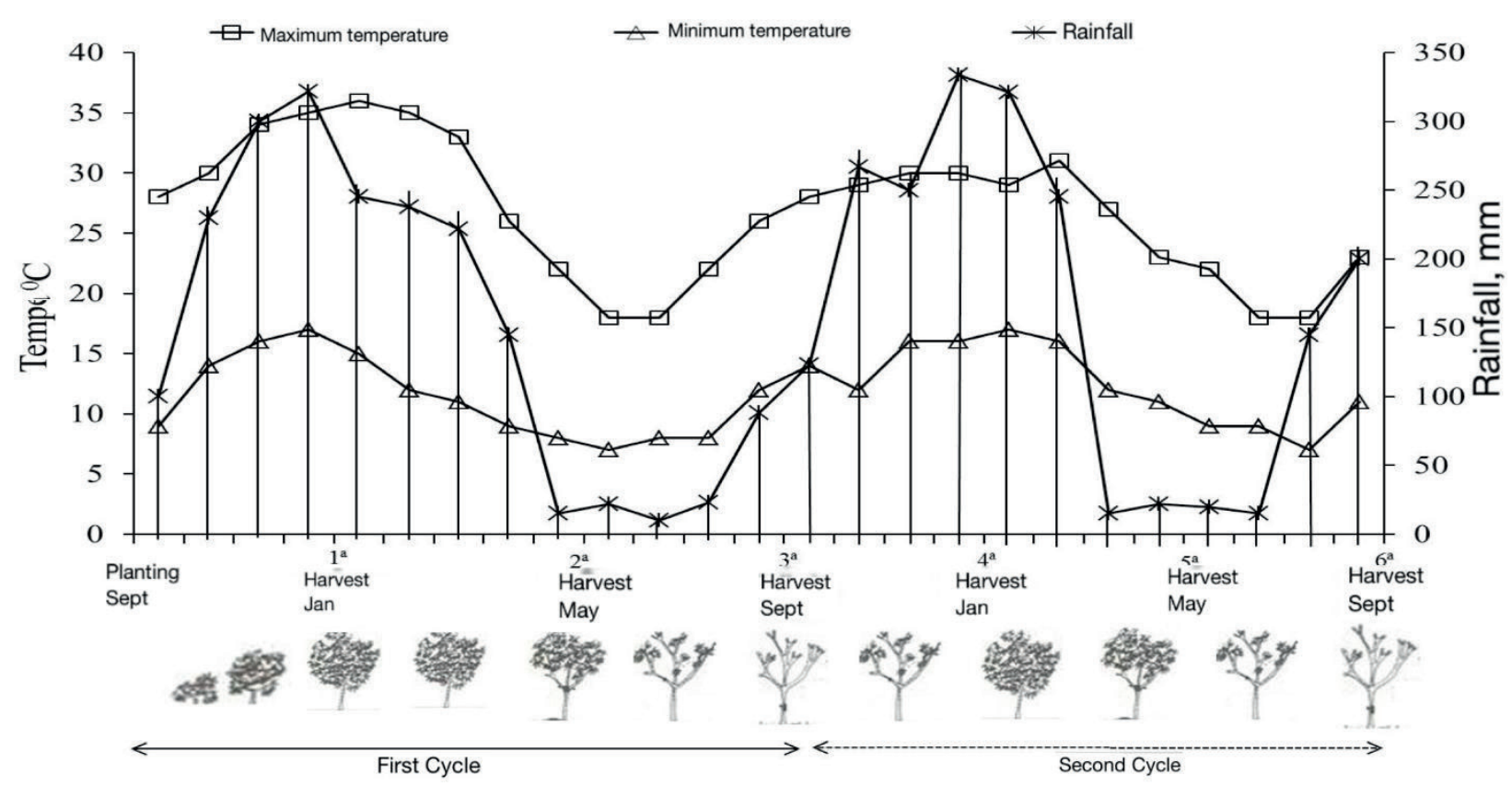

Source: Adapted from CIIAGRO, depicting data prepared by the Campinas Agronomic Institute (IAC), on the vegetative cycles of cassava in the Paulista plateau. 
Table 1. Cassava cultivars with different aerial part architecture, in their respective spacing and densities.

\begin{tabular}{lcccc}
\hline Cultivars & \multicolumn{4}{c}{$\begin{array}{c}\text { Plant densities } \\
\text { (Plants ha' }^{-1}\end{array}$} \\
\hline 'BSC' & 5,000 & 13,000 & 21,000 & 29,000 \\
'IAC 13' & 7,000 & 15,000 & 23,000 & 31,000 \\
'IAC 14-18' & 9,000 & 17,000 & 25,000 & 33,000 \\
'Fibra' & 11,000 & 19,000 & 27,000 & 35,000 \\
\hline
\end{tabular}

The area was prepared with the use of a disk plow at a depth of $20 \mathrm{~cm}$; there was no need to use a leveling grid because of the sandy texture of the soil. The planting was done in a groove, in which the spacing between rows was fixed at 100 $\mathrm{cm}$, only the distance between plants in the crop lines was changed, according to the density used. Planting was carried out with sufficient number of maniocs to meet the final population of each cultivar (Table 1).

The maniocs of each cultivar were collected at the site where the research was conducted. Maniocs of good physiological and sanitary quality, $20 \mathrm{~cm}$ long, with approximately five buds, were used for planting, as recommended by Alves (2006), and distributed horizontally in the grooves.

The experimental design was randomized blocks, with two replications. The treatments were arranged in subdivided plots. The plots represented the cultivars with their respective plant densities (Table 1), and the subplots by the harvesting times 120, 240, 360, 480, 600 and 720 days after planting (DAP).

The basic characteristics used to measure cassava growth were leaf area $\left(\mathrm{A}_{1}\right)$ and total dry mass $\left(\mathrm{W}_{\mathrm{t}}\right)$. The recorded observations were tabulated and analyzed using regression equations, in order to estimate the growth tendencies of cassava plants according to their architecture and planting densities. $\mathrm{W}_{\mathrm{t}}$ was obtained from six plants per plot, and then separated into roots, leaves, branches, and stump. A $0.5 \mathrm{~kg}$ sample of each part was taken for oven drying at the initial temperature of $65^{\circ} \mathrm{C}$ until reaching constant mass, and subsequently weighed.

The leaf area $\left(\mathrm{A}_{1}\right)$ was determined from a sample of 15 leaf blades, five of which were basal, five apical, and five from the middle, sampled from two plants taken at random by subplot. For the determination of the leaf areas, the LI-3100 area meter was used, following the equation proposed by Schons et al. (2007). As the collections started at 120 days, the leaf area corresponding to one third of the observed values was estimated at 60 days. These values are obtained based on the verification of experiments over years of research, and thus are possible to be estimated. The leaf area index (L) was calculated using the formula:

$$
\mathrm{L}=\mathrm{A}_{\mathrm{f}} / \mathrm{S}_{\mathrm{t}}
$$

Where $\mathrm{S}_{\mathrm{a}}$ is the surface area of the soil occupied by the plant. The primary accumulated dry mass data $\left(\mathrm{W}_{\mathrm{t}}\right)$ were adjusted by orthogonal polynomials in relation to harvest times (IEZZI, 2006). From the primary measurements, the functional growth analysis was performed through the parameters of growth analysis, by determining the instantaneous values: leaf area ratio $\left(\mathrm{L}_{\mathrm{a}}\right)$, relative growth rate $\left(\mathrm{R}_{\mathrm{w}}\right)$, and net assimilation rate $\left(\mathrm{E}_{\mathrm{a}}\right)$, estimated respectively by the equations:

$$
\mathrm{R}_{\mathrm{w}}=1 / \mathrm{W}_{\mathrm{t}} \cdot \mathrm{d}_{\mathrm{w}} / \mathrm{d}_{\mathrm{t}} \quad \mathrm{E}_{\mathrm{a}}=1 / \mathrm{A}_{\mathrm{f}} \cdot \mathrm{d}_{\mathrm{w}} / \mathrm{d}_{\mathrm{t}}
$$

Where $d_{w} / d_{t}$ is the derivative of the dry mass equation of the aerial plant parts in relation to: the time, leaf area, weight of leaves, dry matter, and $\mathrm{W}_{\mathrm{t}}$, according to Radford (1967). 
The data were thus analyzed based on the fact that the growth analysis followed simple logistics and did not meet the basic assumptions of the analysis of variance, with non-additive and nonlinear models. In addition, errors are correlated over time and thus are not independent (PORTES; CASTRO JÚNIOR, 1991; DIAS; BARROS, 2009).

In this sense, the quantitative data of growth along the vegetal development were verified through growth tendency curves (RADFORD, 1967). For the analysis of variance and the estimation of the models and their respective regression coefficients, we used the software Sisvar (FERREIRA, 2011), the LAB Fit Curves package (SILVA et al., 2004), and
R software (R DEVELOPMENT CORE TEAM, 2014).

\section{Results and Discussion}

The adjusted equations for the average of total dry matter $\left(\mathrm{W}_{\mathrm{t}}\right)$ estimates of the four cassava cultivars, in their respective population densities and harvesting times, can be observed in Figure 2. There was a significant difference $(p<0.05)$, between the different planting densities and the different harvesting times, however, no significant difference was observed among population densities in the cultivars.

Figure 2. Average of total dry mass $\left(\mathrm{W}_{\mathrm{t}}\right)$ of four cassava cultivars, as a function of planting density and harvesting time, in two vegetative cycles.
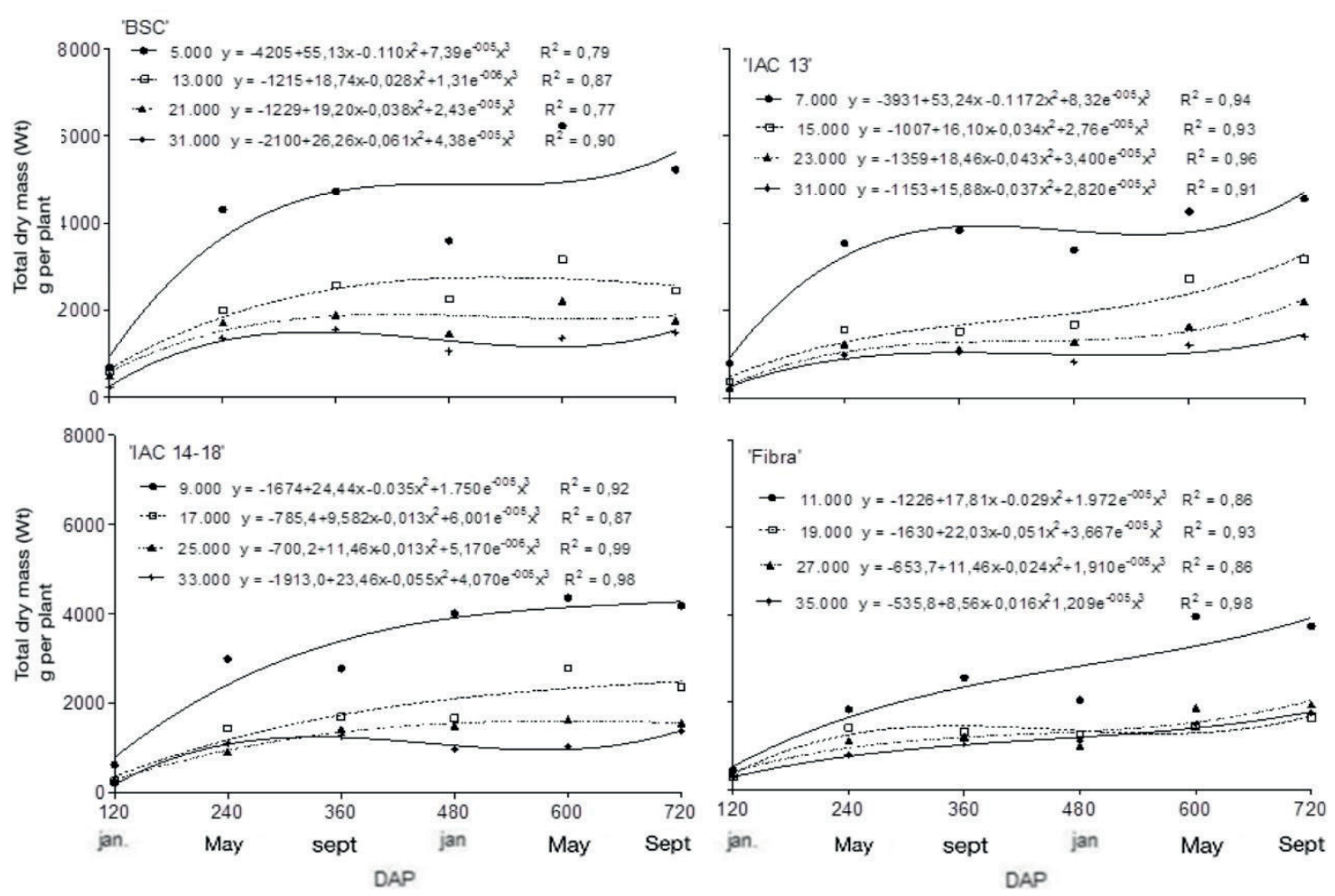

In all cultivars, increasing the population density reduced the dry mass per plant. These results corroborate those of Takahashi and Guerini (1998), who in smaller populations of cassava plants, found a greater number of tuberous roots and higher $\mathrm{W}_{t}$ per plant. However, the responses to the spacings

are variable, due to the specific behavior of each cultivar.

It was verified for all cultivars that over time $\mathrm{W}_{\mathrm{t}}$ adjusted better to the third-order polynomial regression model. These models, according to 
Poorter (1989), and Heinen (1999), allow growth to be robust, and potentially greatly complex. However, these authors suggest that these models are avoided for annual crops because polynomial functions tend to make unrealistic predictions, especially at the extremes of the data. On the other hand, for perennial crops these models predict the plant growth well as a function of the development cycles. Similar $\mathrm{W}_{\mathrm{t}}$ adjustments were reported by Aguiar et al. (2011), who found variations in $\mathrm{W}_{t}$ values for the months of April to June, because the plants were in foliar senescence or already defoliated. This justification can also explain the results observed in the present study. The initial growth of $\mathrm{W}_{\mathrm{t}}$ from 120 to $240 \mathrm{DAP}$ is high, because in this phase the leaves are capable of intercepting much of the light that reaches the canopy of the plants. In this same period, cassava plants acquire the maximum development of the aerial part, and the largest partition assimilated to the leaves and the branches (EL-SHARKAWY, 2004; ALVES, 2006).

On average, the $\mathrm{W}_{\mathrm{t}}$ reduction as a function of the increase in plant numbers per hectare, was 5229 to 1472 g plant $^{-1}$ for 'BSC' at 720 DAP, which corresponds to approximately a $72 \%$ reduction in yields per plant. For the other cultivars, the reduction in the total yield of $\mathrm{W}_{\mathrm{t}}$ at the end of the second cycle was $69 \%, 67 \%$, and $53 \%$, for 'IAC
13', 'IAC14-18', and 'Fibra' respectively (Figure 2 ). The reduction of $\mathrm{W}_{t}$ per plant is due to greater competition, mainly for light. At higher densities plants have their light availability reduced due to shading by neighboring plants. The fact that there is less light inside the leaf canopy can reduce the photosynthetic activity, compromising or even paralyzing it, which will cause the consumption of carbohydrates by respiration, providing a lower balance of assimilates generated by liquid photosynthesis (TAIZ; ZEIGER, 2013).

The results of the production of $\mathrm{W}_{\mathrm{t}}$ per plant are important in the study of planting densities, since the effect of planting density is multiplicative in scale, depending on the number of plants per unit area of each density evaluated. Most of the studies on plant numbers concentrate on productivity per area, not considering an important parameter for the analysis of production quality, and better observed individually.

Differences were observed between plant densities in relation to leaf area $\left(\mathrm{A}_{1}\right)$, and leaf area index $(\mathrm{L})$, for each cultivar evaluated, due to the diversity of aerial part architecture. However, a similar behavior was observed for the cultivars as a function of the number of plants per area, in the adjustments of the curves that presented a quadratic response $(p \leq 0.01)$, with the age of the plants (Table 2).

Table 2. Regression models for the leaf area index (L), of four cassava cultivars with different aerial part architecture, as a function of plant density.

\begin{tabular}{cccc}
\hline Cultivars & Plant densities $\left(\right.$ Plants ha $\left.^{-1}\right)$ & Regression equations & $\mathrm{R}^{2}$ \\
\hline \multirow{3}{*}{ 'BSC' } & 5,000 & $\mathrm{y}=0.0034 \mathrm{x}^{2}-0.134 \mathrm{x}+1.583^{* *}$ & 0.84 \\
& 13,000 & $\mathrm{y}=0.0111 \mathrm{x}^{2}-0.405 \mathrm{x}+4.290^{* *}$ & 0.85 \\
21,000 & $\mathrm{y}=0.0156 \mathrm{x}^{2}-0.575 \mathrm{x}+6.128^{* *}$ & 0.88 \\
& 29,000 & $\mathrm{y}=0.0168 \mathrm{x}^{2}-0.680 \mathrm{x}+8.451^{* *}$ & 0.89 \\
\hline \multirow{3}{*}{ 'IAC 13' } & 7,000 & $\mathrm{y}=0.0132 \mathrm{x}^{2}-0.457 \mathrm{x}+3.920^{* *}$ & 0.91 \\
& 15,000 & $\mathrm{y}=0.0244 \mathrm{x}^{2}-0.827 \mathrm{x}+6.931^{* *}$ & 0.90 \\
& 23,000 & $\mathrm{y}=0.0301 \mathrm{x}^{2}-1.011 \mathrm{x}+8.598^{* *}$ & 0.85 \\
& 31,000 & $\mathrm{y}=0.0503 \mathrm{x}^{2}-1.691 \mathrm{x}+14.202^{* *}$ & 0.87 \\
\hline
\end{tabular}


continuation

\begin{tabular}{llll}
\hline & 9,000 & $\mathrm{y}=0.0084 \mathrm{x}^{2}-0.298 \mathrm{x}+2.805^{* *}$ & 0.87 \\
'IAC 14-18' & 17,000 & $\mathrm{y}=0.0160 \mathrm{x}^{2}-0.563 \mathrm{x}+5.201^{* *}$ & 0.79 \\
& 25,000 & $\mathrm{y}=0.0176 \mathrm{x}^{2}-0.612 \mathrm{x}+5.940^{* *}$ & 0.87 \\
& 33,000 & $\mathrm{y}=0.0224 \mathrm{x}^{2}-0.821 \mathrm{x}+8.707^{* *}$ & 0.89 \\
\hline & 11,000 & $\mathrm{y}=0.0086 \mathrm{x}^{2}-0.3310 \mathrm{x}+3.729^{* *}$ & 0.79 \\
'Fibra' & 19,000 & $\mathrm{y}=0.0115 \mathrm{x}^{2}-0.4855 \mathrm{x}+5.679^{* *}$ & 0.80 \\
& 27,000 & $\mathrm{y}=0.0181 \mathrm{x}^{2}-0.7313 \mathrm{x}+8.781^{* *}$ & 0.84 \\
& 35,000 & $\mathrm{y}=0.0264 \mathrm{x}^{2}-0.978 \mathrm{x}+10.706^{* *}$ & 0.85 \\
\hline
\end{tabular}

${ }^{* *}$ Significant at $(\mathrm{p}<0.01)$.

The highest plant densities showed the highest leaf area indexes, and the tendency observed in the cultivars was to reduce up to 540 DAP (Figure 3). It was observed that leaf area index (L) significantly increased in response to increased plant density. This corroborates Maria and Ramos (2007) arguments, which stated plant densification was effective in raising the leaf area index of the castor bean crop, can be a viable strategy to reduce soil erosion, and favor the cultural management of weeds among other advantages.

Figure 3. Leaf area index (L) of four cassava cultivars, as a function of planting density and harvesting time, in two vegetative cycles.
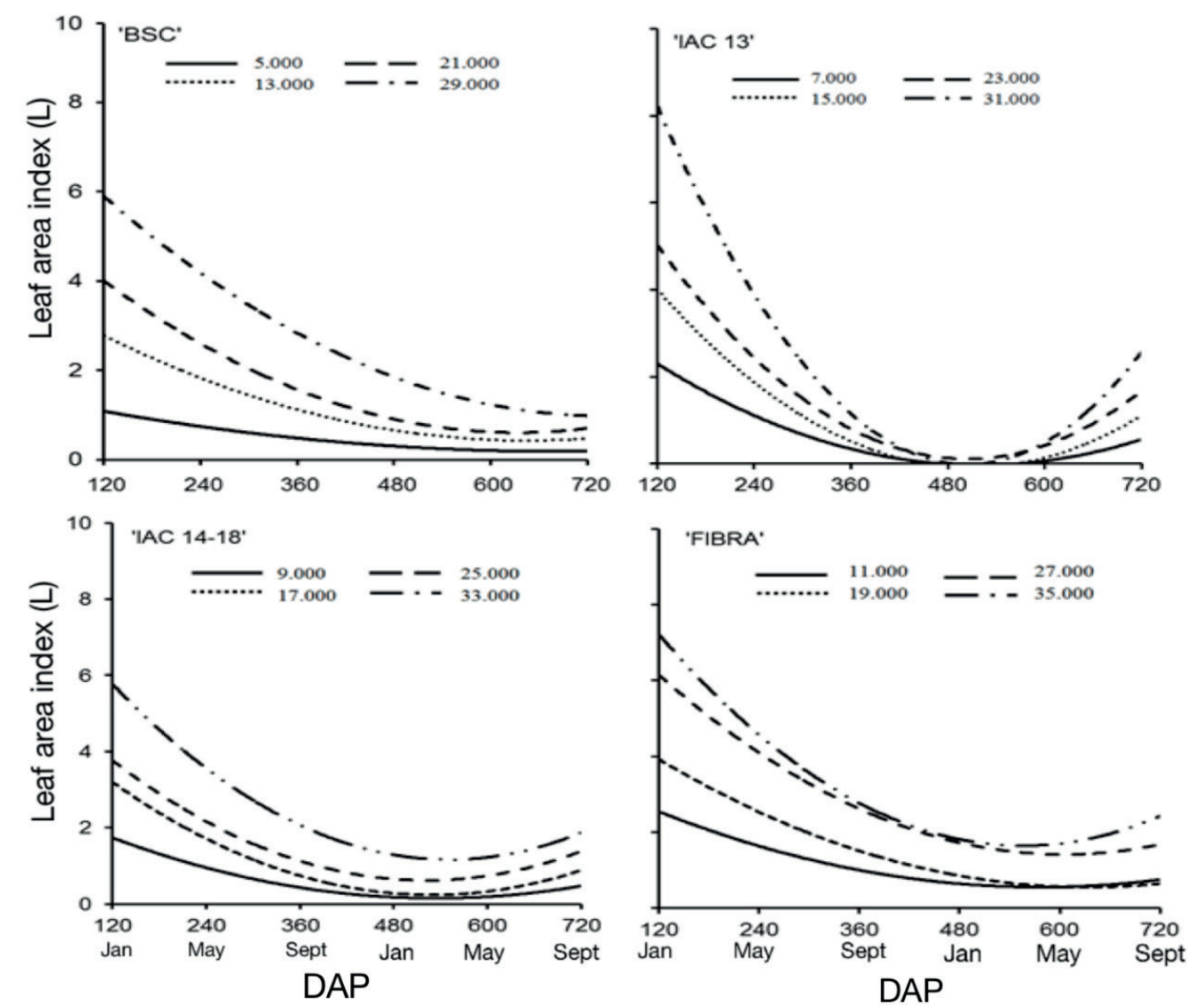
When analyzing the intermediate densities in the cultivars, it is possible to observe that from 120 DAP, the leaf area index (L) increased from 3.0 to 4.1 for 'BSC', at densities of $13,000 \mathrm{ha}^{-1}$ and $21,000 \mathrm{ha}^{-1}$, respectively. 'IAC 13', had a leaf area index (L) of 4.0 and 5.1, at densities of 15,000 plants $\mathrm{ha}^{-1}$ and 23,000 plants $\mathrm{ha}^{-1}$ respectively. At a density of 17,000 plants ha', 'IAC 14-18' had a leaf area index of 3.9 from 120 DAP. 'Fibra' at 15,000 plants ha $\mathrm{h}^{-1}$ and 23,000 plants ha ${ }^{-1}$, showed a leaf area index of 3.2 and 3.8 respectively (Figure 3 ). The most expressive result regarding the leaf area index (L) and its relationship with planting densities, was 'IAC 13 ' in the highest plant density of 35,000 plants ha ${ }^{-1}$. High values of L imply substantial foliar abscission, which may reduce the growth of roots due to the detriment of the aerial part. Similar results were reported for other crops such as soybeans (HEIFFIG et al., 2006), maize (ALVAREZ et al., 2006), and canola (CHAVARRIA et al., 2011).

Leaf area index (L) values for intermediate densities are around 3.5, the value reported by Cock (1989), as ideal for cassava cultivation with $90 \%$ interception of the photosynthetically active radiation flux. According to Schons et al. (2007), these differences found in the leaf area index between the smallest and largest plant populations, can cause a reduction in liquid photosynthesis, influencing the final productivity due to production limitation and carbohydrate accumulation. The high $\mathrm{L}$ values observed in the higher plant densities were expected and explained by the high senescence of the basal leaves. The maximum $\mathrm{L}$ values observed in this study are consistent with those reported by Baker et al. (1989), for a cassava variety cultivated in a subtropical region, whose maximum $L$ was 8.0 at 168 days after planting and decreased to 3.0 at 234 days. It is hypothesized that the variations in $\mathrm{L}$ as a function of the number of plants per area, is explained in the branching pattern. Branching pattern determines the active apices, thus a greater longevity and leaf size per apex is maintained, due to the variation in the architecture of the studied plants.

The leaf area ratio $\left(\mathrm{L}_{\mathrm{a}}\right)$ is how much each unit of dry mass formed in the plant is invested in the formation of leaf area. The regression equations estimate the variation of $\mathrm{L}_{\mathrm{a}}$ as a function of time. $\mathrm{L}_{\mathrm{a}}$ is appropriate for evaluating the genotypic and climatic effects between different cultivars (PEREIRA; MACHADO, 1987). For Benincasa (2004), this physiological index is a morphological component of the growth analysis, which has a general tendency to decrease as the plant grows, as with increased growth, the useful leaf area tends to decrease.

It was verified in this study that all cultivars presented the maximum $\mathrm{L}_{\mathrm{a}}$ at $120 \mathrm{DAP}$, after which, the values decreased until the end of the first cycle at 360 DAP. With the beginning of the second vegetative cycle, they returned, but at a reduced growth than was observed in the first cycle (Figure 4). 
Figure 4. Leaf area ratio $\left(\mathrm{L}_{\mathrm{a}}\right)$ of four cassava cultivars, as a function of planting density and harvesting time, in two vegetative cycles.

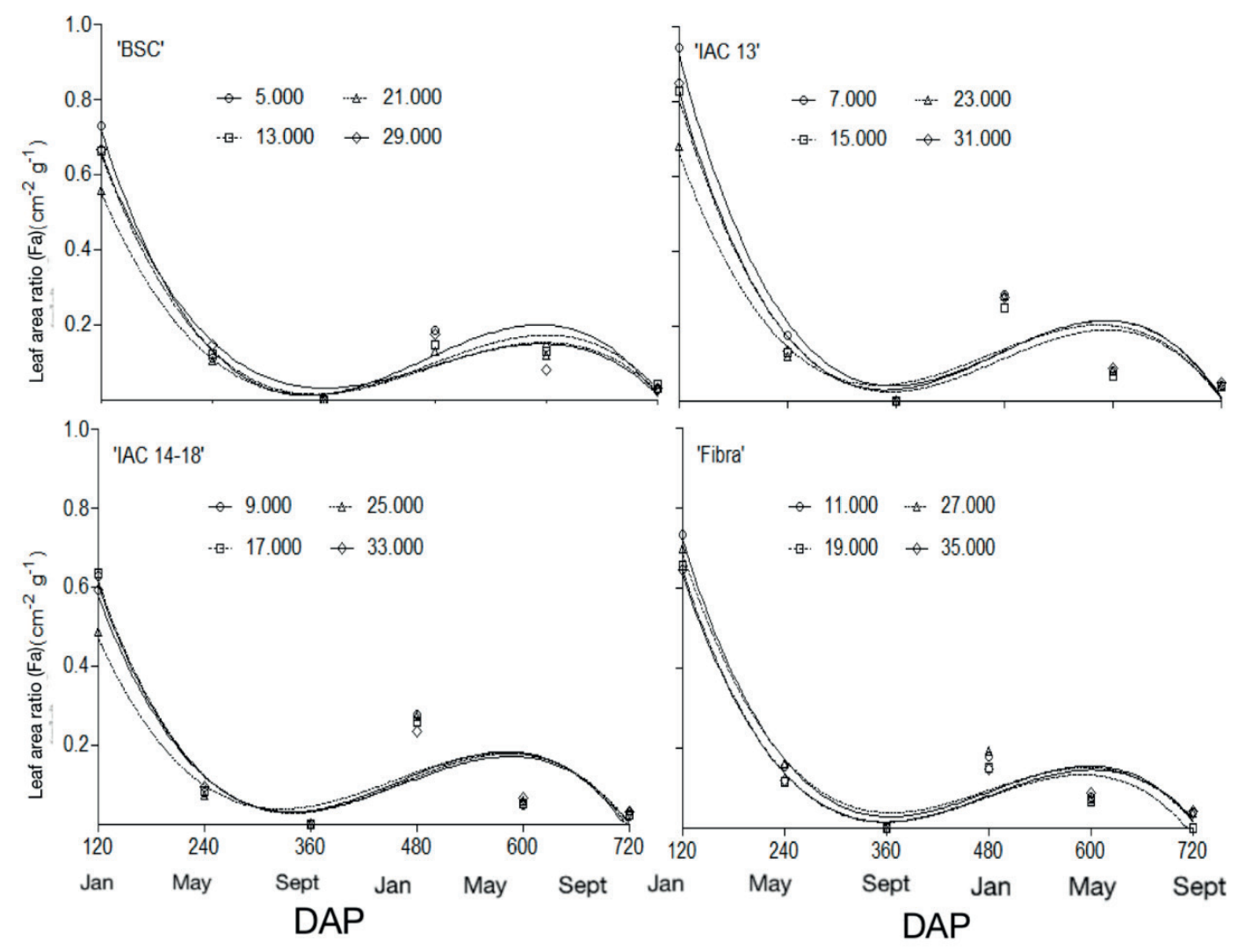

Among the cultivars analyzed at 120 DAP, at the lowest planting density 'IAC 13' showed greater potential in dry matter accumulation to form approximately $1.0 \mathrm{~cm}^{-2}$ of leaf, whereas 'IAC 14-18' formed about $0.6 \mathrm{~cm}^{-2}$ per unit of dry mass. The other two cultivars presented intermediate results. The highest $\mathrm{L}_{\mathrm{a}}$ values occurred at the lowest densities. In the second cycle, investment in leaf formation fell, and all cultivars, regardless of the density studied, had a $\mathrm{L}_{\mathrm{a}}$ value around $0.2 \mathrm{~cm}^{-2} \mathrm{~g}^{-1}$. Thus, the leaf as a source of dry matter, does not have as much priority for the plant after the tuberous roots are formed, having been more intense from the fourth month (Figure 4).

Cassava plants submitted to stress conditions and intraspecific competition tend to significantly reduce transpiration through a winding leaf pattern (EL-SHARKAWY, 2007), foliar abscission of older leaves (WRIGHT et al., 1983), and reduction of leaf growth by restriction of elongation and number of cells (ALVES; SETTER, 2004). In the present study, this behavior was verified and reflected in the $L_{a}$ variation. This represents a positive species adaptation to low water availability, a condition which occurs frequently at the end of the vegetative cycles.

Another aspect that results in the decline of $\mathrm{L}_{\mathrm{a}}$ curves is the appearance of non-assimilatory tissues, mainly of the more lignified stems, that compete decisively with the vegetative structures for the assimilates produced. Alvarez et al. (2005), when evaluating the growth of two peanut cultivars through studying their physiological indexes, verified the decrease in $\mathrm{L}_{\mathrm{a}}$ with the development of the plant. These results resemble those observed by Gomide et al. (2003), and Oliveira et al. (2000), who used physiological indexes when evaluating Panicum maximum Jacq cv. Colonião, and Cynodon 
spp., respectively.

The relative growth rate $\left(\mathrm{R}_{\mathrm{w}}\right)$ represents the amount of dry matter formed from one unit of dry matter per day. $\mathrm{R}_{\mathrm{w}}$ can be considered as an efficiency index, since it represents the plant's ability to produce new material, it can be deduced that this variable is influenced during the phenological cycle. In addition, Radford (1967), and Chiariello et al. (1991), argue that this physiological index is the most appropriate to compare effects of different agronomic management styles, because it is relative, and not dependent on mathematical presuppositions. The regression curves represent the variation of $\mathrm{R}_{\mathrm{w}}$ as a function of the age of the cassava cultivars at different planting densities (Figure 5).

The general tendency for $\mathrm{R}_{\mathrm{w}}$ is its reduction as the development of the cassava crop cycle occurs (Figure 5). In general, at 120 DAP, the averages for the studied cultivars, regardless of plant density, were between 0.07 and $0.08 \mathrm{~g} \mathrm{~g}^{-1}$ day $^{-1}$. These values decrease and become negative close to 240 DAP and reached minimum values at the end of the first cycle, with a subsequent increase. Regardless of the planting density, 'Branca de Santa Catarina' and 'IAC 13', presented a $\mathrm{R}_{\mathrm{w}}$ close to $0.02 \mathrm{~g} \mathrm{~g}^{-1}$ day $^{-1}$. Similar results were reported by Begum and Paul (2005) in cassava, which verified the decrease of $R_{w}$ due to falling older leaves.

In addition to leaf fall, other factors such as different cultivars and climatic variations influence $\mathrm{R}_{\mathrm{w}}$ values (LINDSAY et al., 2012; HOUGHTON et al., 2013). The increase in $R_{w}$ that occurred at the beginning of the second cycle in all cultivars, is probably due to the increased efficiency in the accumulation of material, when there is a translocation of photoassimilates to the tuberous roots. This behavior of $\mathrm{R}_{\mathrm{w}}$ is widely reported in the literature, as in Benincasa (2004), Alvarez et al. (2005), and Alves (2006).

Figure 5. Relative growth rate $\left(\mathrm{R}_{\mathrm{w}}\right)$ of four cassava cultivars, as a function of planting density and harvesting time, in two vegetative cycles.
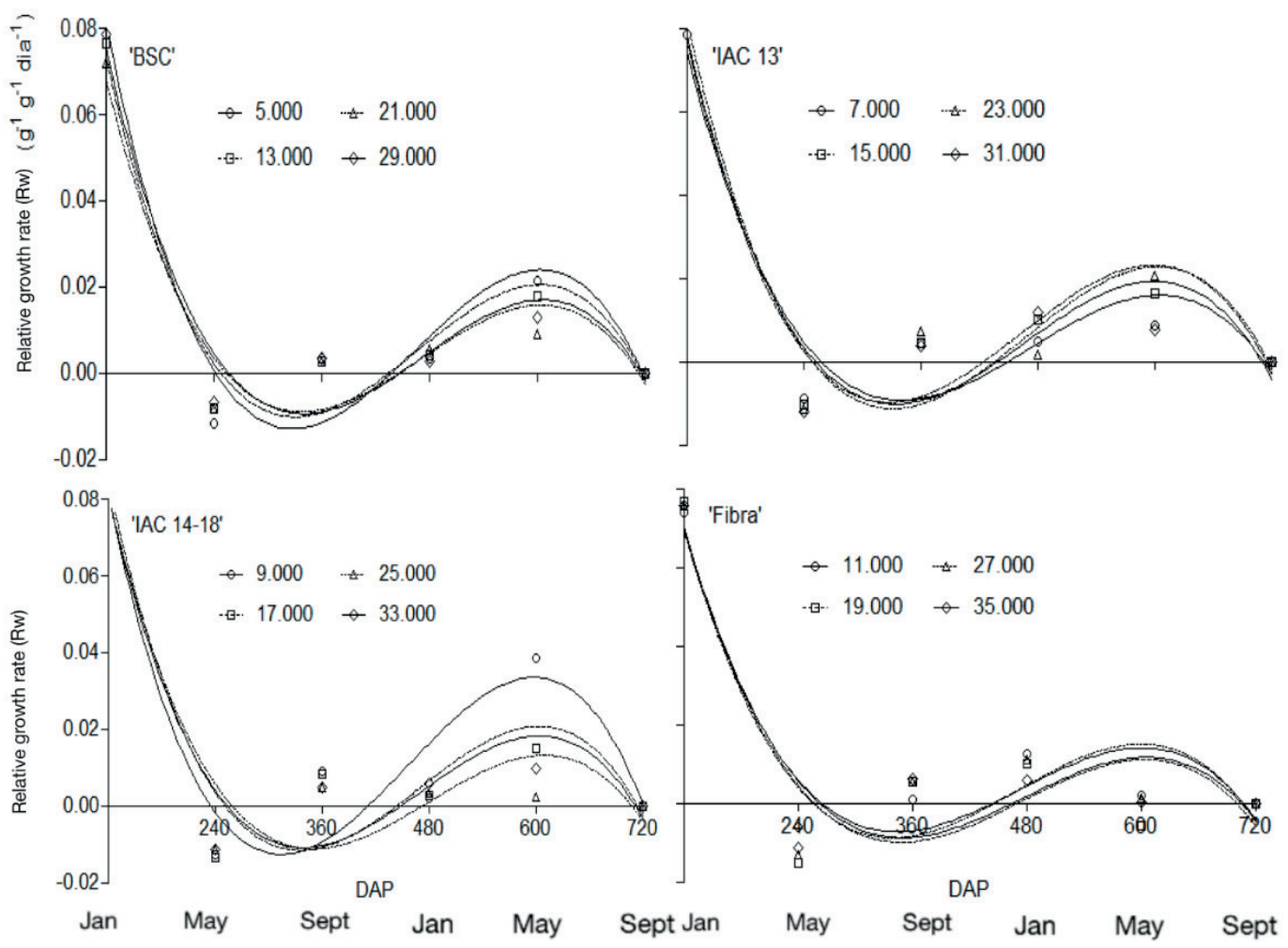
The $\mathrm{R}_{\mathrm{w}}$ values, estimated from the equations, range between -0.02 to $0.08 \mathrm{~g}^{-1}$ day $^{-1}$ for the four cultivars. A negative $\mathrm{R}_{\mathrm{w}}$ from 240 to 420 DAP indicated that the plants were producing less energy than they were consuming. Therefore, there was no new organ development, but a consumption of reserves (Figure 5). It is worth mentioning the negative values of $\mathrm{R}_{\mathrm{w}}$, revealing the high respiratory demand, due to lower vegetative biomass and high reserve root development. These expenses are probably due to the respiration for growth, the transport and the transformation of the photoassimilates in different substances inside the plant, as well as the respiration for maintenance.

Besides the decrease observed in the first cycle, it is possible to verify the curve growth after the beginning of the second cycle. This occurred from 390 DAP, and is related to the growth of the new leaf area, useful for photosynthesis, and consequently to the reduction of the respiration rate. According to Benincasa (2004), growth will result from the production of sufficient material to meet the metabolic needs of the existing material, and also to store or construct new structural material. This is as conceptually, growth analysis establishes that the growth rate of a plant is a function of the initial size, that is, the period in which the observation begins, and in this case represents the second development cycle of cassava plants.

The net assimilation rate $\left(\mathrm{E}_{\mathrm{a}}\right)$, consists of the size of the assimilator system that is involved in the production of dry matter, therefore it is an estimate of the liquid photosynthesis, and depends on environmental factors, mainly solar radiation. The plant growth response to environmental conditions is useful for comparative studies among cultivars and measures the efficiency of a plant in the production of dry matter mass. $\mathrm{E}_{\mathrm{a}}$, as well as $\mathrm{R}_{\mathrm{w}}$, decreased with plant age from 120 to 270 DAP (Figure 6). Since $\mathrm{E}_{\mathrm{a}}$ is expressed as the liquid photosynthesis rate, in terms of dry matter produced per centimeter of leaf area, per time interval (BENINCASA, 2004), the negative values indicate that there was no growth, but a consumption of reserves. The described behavior is in agreement with the reports of Giacomini et al. (2009). However, the values obtained were higher than those verified by Oliveira and Fiorine (2006), for cultivation of cassava seedlings from stakes in different containers, probably due to plant age.

Figure 6. Net assimilation rate $\left(\mathrm{E}_{\mathrm{a}}\right)$ of four cassava cultivars, as a function of planting density and harvesting time, in two vegetative cycles.
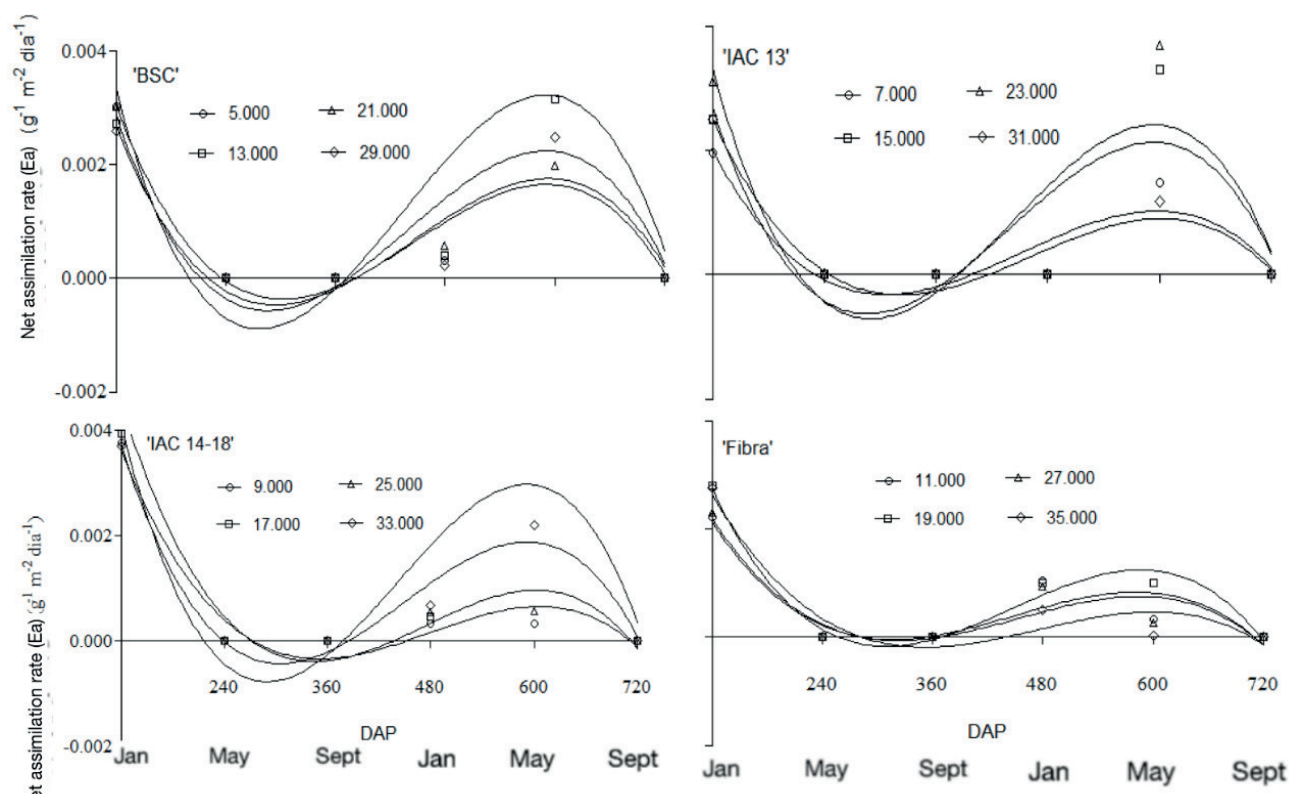

Semina: Ciências Agrárias, Londrina, v. 40, n. 1, p. 113-126, jan./fev. 2019 
Respiration has been functionally separated into respiration for growth and maintenance. Growth respiration competes for the synthesis of new biomass, and is proportional to the liquid photosynthetic rate, while maintenance respiration competes for the recycling of existing compounds and is proportional to the plant biomass (HAY; WALKER, 1989; KRAUSS et al., 1989). Respiratory losses are extremely variable, depending on the environment and management conditions, and can reach up to $60 \%$ of the fixed carbon (KRAUSS et al., 1989).

The 'BSC' cultivar, more strongly in the density of 5,000 plants ha- ${ }^{-1}$, proved to be efficient in increasing $E_{a}$ at the beginning of the second vegetative cycle, reaching a maximum value of $0.00368 \mathrm{~g}^{-1} \mathrm{~m}^{-2}$ day $^{-1}$ at approximately 570 DAP. In comparison 'IAC 13', the maximum $\mathrm{E}_{\mathrm{a}}$ values for intermediate planting densities $(15,000$ and 23,000 plants $\mathrm{ha}^{-1}$ ), had observed values of 0.00234 and $0.00251 \mathrm{~g} \mathrm{~g}^{-1} \mathrm{~m}^{-2}$ day $^{-1}$ at $570 \mathrm{DAP}$, respectively. Similarly, 'IAC 14-18' at intermediate densities of 17,000 and 25,000 plants ha $^{-1}$, had observed values of 0.00281 and $0.00188 \mathrm{~g}^{-1} \mathrm{~m}^{-2}$ day $^{-1}$ respectively For 'Fibra', the $\mathrm{E}_{\mathrm{a}}$ growth occurred from 390 DAP, fitted more smoothly to the curve, and did not differ statistically from the densities studied (Figure 6).

It was demonstrated in this study that the variation in L, was a function of the different cultivars, and also due to the influence of the plant density. Because the cassava crop has a long cultivation cycle, the leaf area controls the accumulation of photoassimilates, as well as the final productivity. However, as cassava is usually cultivated in poor and acidic soils and is subject to dry periods, the crop loses a considerable part of its leaf area often early, which contributes to a rapid decrease in both leaf area and growth parameters, such as $\mathrm{R}_{\mathrm{w}}$ and $\mathrm{E}_{\mathrm{a}}$.

\section{Conclusions}

When the plants are considered individually, all cultivars accumulated more total dry mass $\left(\mathrm{W}_{\mathrm{t}}\right)$, at the lowest planting densities. At 120 days after planting, when the cassava plants had a higher leaf area ratio $\left(\mathrm{L}_{\mathrm{a}}\right)$, the values were higher for 'IAC 13' and lower for 'IAC 14-18'.

Relative growth rates $\left(\mathrm{R}_{\mathrm{w}}\right)$ of the cultivars varied strongly with the plant population only in the second cycle, 'IAC 14-18' showed greater dependency on spacing, while 'Fibra' presented lower dependency on spacing.

\section{References}

AGUIAR, E. B.; VALLE, T. L.; LORENZI, J. O.; KANTHACK, R. A. D.; MIRANDA FILHO, H.; GRANJA, N. P. Efeito da densidade populacional e época de colheita na produção de raízes de mandioca de mesa. Bragantia, Campinas, v. 70, n. 2, p. 561-569, 2011.

AKINWALE, M. G.; ALADESANWA, R. D.; AKINYELE, B. O.; DIXON, A. G. O.; ODIYI, A. C. Inheritance of $\beta$-carotene in cassava (Manihot esculenta crantz). International Journal of Genetics and Molecular Biology, Nairóbi, v. 2, n. 10, p. 198-201, 2010.

ALVAREZ, C. G. D.; PINHO, R. G. V.; BORGES, I. D. Avaliação de características agronômicas e de produção de forragem e grãos de milho em diferentes densidades de semeadura e espaçamentos entre linhas. Ciência e Agrotecnologia, Lavras, v. 30, n. 3, p. 402-408, 2006.

ALVAREZ, R. de C. F.; RODRIGUES, J. D.; MARUBAYASHI, M. O.; ALVAREZ, A. C. C.; CRUSCIOL, C. A. C. Análise de crescimento de duas cultivares de amendoim (Arachis hypogaea L.). Acta Scientiarum Agronomy, Maringá, v. 27, n. 4, p. 611-616, 2005.

ALVES, A. A. C. Fisiologia da mandioca. In: SOUZA. L. S. da. Aspectos socioeconômicos e agronômicos da mandioca. Cruz das Almas: EMBRAPA Mandioca e Fruticultura Tropical, 2006. p. 138-169.

ALVES, A. A. C.; SETTER, T. L. Response of cassava leaf area expansion to water deficit: cell proliferation, cell expansion and delayed development. Annals of Botany, London, v. 94, n. 1, p. 605-613, 2004.

AYOOLA, O. T. Effects of fertilizer treatments on soil chemical properties and crop yields in a cassava based Cropping System. Journal of Applied Sciences Research, Pakistan, v. 2, n. 12, p. 1112-1116, 2006.

AYOOLA, O. T.; MAKINDE, E. A. Influence of cassava population density on the growth and yield performance 
of cassava-maize intercrop with a relayed cowpea. Tropical and Subtropical Agroecosystems, Mexico, v. 8, n. 4, p. 235-241, 2008.

BAKER, G. R.; FUKAI, S.; WILSON, G. L. The response of cassava to water deficits at various stages of growth in the subtropics. Journal of Agricultural Research, Washington, v. 40, n. 3, p. 517-528, 1989.

BEGUM, S.; PAUL, N. K. Growth analysis of cassava (Manihot esculenta L.) varieties in relation to time of planting. Bangladesh Journal Botany, Bangladesh, v. 34, n. 2, p. 21-26, 2005.

BENINCASA, M. M. P. Análise de crescimento de plantas: noções básicas. Jaboticabal: FUNEP, 2004. 42 p.

CHAVARRIA, G.; TOMM, G. O.; MULlER, A.; MENDONÇA, H. F.; MELlO, N.; BETTO, M. S. Índice de área foliar em canola cultivada sob variações de espaçamento e de densidade de semeadura. Ciência Rural, Santa Maria, v. 41, n. 12, p. 2084-2089, 2011.

CHIARIELLO, N. R.; MOONEY, H. A.; WILLIAMS, K. Growth, carbon allocation and cost of plant tissues. In: PEARCY, R. W.; EHLERINGER, J. R.; MOONEY, H. A. (Ed.). Plant physiologycal ecology: fields and instrumentation. New York: Chapman and Hall, 1991. p. 328-365.

COCK, J. H. La Yuca, nuevo potencial para um cultivo tradicional. Cali: Centro Internacional de Agricultura Tropical, 1989. $240 \mathrm{p}$.

DIAS, L. A. S.; BARROS, W. S. Biometria experimental. Viçosa, MG: Suprema Gráfica e Editora Ltda, 2009. 408 p.

EL-SHARKAWY, M. A. Cassava biology and physiology. Plant Molecular Biology, Springer, v. 56, n. 1, p. 481-501, 2004.

Physiological characteristics of cassava tolerance to prolonged drought in the tropics: implications for breeding cultivars adapted to seasonally dry and semiarid environments. Brazilian Journal of Plant Physiology, Londrina, v. 19, n. 4, p. 257-286, 2007.

EMPRESA BRASILEIRA DE PESQUISA AGROPECUÁRIA - EMBRAPA. Sistema brasileiro de classificação de solos. 3. ed. rev. ampl. Brasília: EMBRAPA, 2013. 353 p.

FOOD AND AGRICULTURE ORGANIZATION OF THE UNITED NATIONS - FAO. Food energy-methods of analysis and conversion factors. Rome: Editora, 2014.

FERREIRA, D. F. Sisvar: a computer statistical analysis system. Ciência e Agrotecnologia, Lavras, v. 35, n. 6, p. 1039-1042, 2011.
FERREIRA, E. A.; MATOS, C. C.; BARBOSA, E. A.; SILVA, D. V.; SANTOS, J. B.; PEREIRA, G. A. M.; FARIA, A. T.; SILVA, C. T. Respostas fisiológicas da mandioca à aplicação de herbicidas. Semina: Ciências Agrárias, Londrina, v. 36, n. 2, p. 645-656, 2015.

GAMEIRO, A. H. Mandioca: de alimento básico à matéria-prima industrial. Piracicaba: Centro de Estudos Avançados em Economia Aplicada, 2002. 28 p.

GIACOMINI, A. A.; SILVA, S. C.; SARMENTO, D. O. de L.; ZEFERINO, C. V.; SOUZA JÚNIOR, S. J.; TRINDADE, J. K.; GUARDA, V. A.; NASCIMENTO JÚNIOR, D. Crescimento do capim-marandu submetido à estratégias de lotação intermitente. Scientia Agricola, Piracicaba, v. 66, n. 6, p. 733-741, 2009.

GOMES, C. N.; CARVALHO, S. P.; JESUS, A. M. S.; CUSTODIO, T. N. Caracterização morfoagronomica e coeficientes de trilha de componentes da produção em mandioca. Pesquisa Agropecuária Brasileira, Brasília, v. 42, n. 8, p. 1221-1130, 2007.

GOMIDE, C. A. M.; GOMIDE, J. A.; ALEXANDRINO, E. Índices morfogênicos e de crescimento durante o estabelecimento e a rebrotação do capim-Mombaça (Panicum maximum Jacques). Revista Brasileira de Zootecnia, Brasília, v. 32, n. 4, p. 795-803, 2003.

HAY, R. K. M.; WALKER, A. J. An introduction to the physiology of crop yield. London: Longman Group, 1989. $292 \mathrm{p}$.

HEIFFIG, L. S.; CÂMARA, G. M. S.; MARQUES, L. A.; PEDROSO, D. B.; PIEDADE, S. M. S. Fechamento e índice de área foliar da cultura da soja em diferentes arranjos espaciais. Bragantia, Campinas, v. 65, n. 2, p. 285-295, 2006.

HEINEN, M. Analytical growth equations and their Genstat 5 equivalents. Netherlands Journal of Agricultural Science, Wageningen, v. 47, n. 1, p. 67-89, 1999.

HOUGHTON, J.; THOMPSON, K.; REES, M. Does seed mass drive the differences in relative growth rate between growth forms? Proceedings of the Royal Society B: Biological Sciences, Sheffield, v. 280, n. 1, p. 1-6, 2013.

HOWE, J.A.; MAZIYA-DIXON, B.; TANUMIHARDJO, $\mathrm{S}$. Cassava with enhanced b-carotene maintains adequate vitamin A status in Mongolian gerbils (Meriones unguiculatus) despite substantial cisisomer content. British Journal of Nutrition, Southampton, v. 102, n. 2, p. 342-349, 2009.

HUNT, R. Growth analysis, individual plants. In: THOMAS, B.; D. J. MURPHY, D. J.; MURRAY, B. G. 
(Ed.). Encyclopaedia of applied plant sciences. Academic Press, London. 2003. 2003. p. 579-588.

IEZZI, G. Fundamentos de matemática elementar: complexos, polinômios e equações. 8. ed. São Paulo: Saraiva, 2006. 356 p.

KRAUSS, E.; WILSON, D.; ROBSON, M. J. Respiration: correlation with growth rate and its quantitative significance for net assimilation rate and biomass production. In: LAMBERS, H.; CAMBRIDGE, M. L.; KONINGS, H.; DOUCE, R.; DAY, D. A. (Ed.). Causes and consequences of variation in growth rate and productivity of higher plants. Hague: The Netherlands, 1989. p. 187-198.

LINDSAY, A. T.; CHRISTOPHER, D. P.; DREW, W. P.; REBECCA, L. A.; JENNIFER, C.; GOODENOUGH, A.; HAUTIER, Y.; HOUGHTON, J.; MARTHEWS, T. R.; OSBORNE, C. P.; PAUL-VICTOR, C.; ROSE, K. E.; SANER, P.; TAYLOR, S. H.; WOODWARD, I.; HECTOR, A.; REES, M. Plant growth rates and seed size: a re-evaluation. Ecology, Oxford, v. 93, n. 6, p. 1283-1289, 2012.

MACHADO, E. C.; PEREIRA, A. R.; FAHL, J. I.; ARRUDA, H. V.; SILVA, W. J.; TEIXEIRA, J. P. F. Analise de crescimento de quatro variedades de milho em três densidades de plantio, através de funções matemáticas ajustadas. Pesquisa Agropecuária Brasileira, Brasília, v. 17, n. 1, p. 825-833, 1982.

MARIA, I. C. de; RAMOS, N. P. Conservação e manejo do solo. In: AZEVEDO, D. M. P. de; BELTRÃO, N. E. de M. (Ed.). O agronegócio da mamona no Brasil. 2. ed. Campina Grande: EMBRAPA Algodão; Brasília: EMBRAPA Informações Tecnológicas, 2007. p. 97-115.

NTAWURUHUNGA, P.; DIXON, A. Quantitative variation and interrelationship between factors influencing cassava yield. Journal of Applied Biosciences, Adis Abeba, v. 26, n. 4, p. 1594-1602, 2010.

OLIVEIRA, M. A.; FIORINE, R. A. Análise de crescimento em mudas de mandioca (Manihot esculenta Crantz) provenientes de estacas em diferentes recipientes para cultivo. Revista Raízes e Amidos Tropicais, Botucatu, v. 2, n. 1, p. 12-26, 2006.

OLIVEIRA, M. A.; PEREIRA, O. G.; GOMIDE, J. A. Análise de crescimento do capim bermuda Tifton 85 (Cynodon spp). Revista Brasileira Zootecnia, Brasília, v. 29, n. 6, p. 1930-1938, 2000.

PEIXOTO, C. P.; MACHADO, G. S.; BORGES, V. P.; ALVES, E. C.; LEAL, G. M. F. Índices fisiológicos de soja hortaliça em duas épocas de semeadura no Recôncavo Sul Baiano. Scientia Agraria Paranaensis, Marechal Cândido Rondon, v. 11, n. 1, p. 56-67, 2012.
PEIXOTO, C. P.; PEIXOTO, M. de F. da S. P. Dinâmica do crescimento vegetal. In: CARVALHO, C. A. L. de; DANTAS, A. C. V. L.; PEREIRA, F. A. de C.; SOARES, A. C. F.; MELO FILHO, J. F. de; OLIVEIRA, G. J. C. de. Tópicos em ciências agrarias. Cruz das Almas: Universidade Federal do Recôncavo da Bahia, 2009. p. 39-53.

PEREIRA, A. R.; MACHADO, E. C. Análise quantitativa do crescimento de comunidades vegetais. Campinas: IAC, 1987. 33 p. (IAC. Boletim técnico, 114).

POORTER, H. Plant growth analysis: towards a synthesis of the classical and the functional approach. Physiologia Plantarum, Denmark, v. 75, n. 2, p. 237-244, 1989.

PORTES, T. A.; CASTRO JÚNIOR, L. G. Análise de crescimento de plantas: um programa computacional auxiliar. Revista Brasileira de Fisiologia Vegetal, Londrina, v. 3, n. 1, p. 53-56, 1991.

R DEVELOPMENT CORE TEAM - R. R. Foundation for Statistical Computing. Vienna: Áustria, 2014.

RADFORD, P. J. Growth analysis formulae: their use and abuse. Crop Science, Kansas City, v. 7, n. 3, p. 171175, 1967.

SCHONS, A.; STRECK, N. A.; KRAULICH, B.; PINHEIRO, D. G.; ZANON JUNIOR, A. Emissão de folhas e início da acumulação de amido em raízes de uma variedade de mandioca em função da época de plantio. Ciência Rural, Santa Maria, v. 37, n. 6, p. 1586-1592, 2007.

SILVA, W. P.; SILVA, C. M. D. P. S.; CAVALCANTI, C. G. B.; SILVA, D. P. S.; SOARES, I. B.; OLIVEIRA, J. A. S.; SILVA, C. D. P. "LAB Fit Ajuste de Curvas": um software em português para tratamento de dados experimentais. Revista Brasileira de Ensino de Física, São Paulo, v. 26, n. 4, p. 419-427, 2004.

TAIZ, L.; ZEIGER, E. Fisiologia vegetal. 5. ed. Porto Alegre: Artmed, 2013. 954 p.

TAKAHASHI, M.; GUERINI, V. L. Espaçamento para a cultura da mandioca. Arquivos de Biologia e Tecnologia, Curitiba, v. 41, n. 4, p. 489-494, 1998.

VIDIGAL FILHO, P. S.; PEQUENO, M. G.; SCAPIM, C. A.; VIDIGAL, M. C. G.; MAIA, R. R.; SAGRILO, E.; SIMON, G. A.; LIMA, R. S. Avaliação de cultivares de mandioca na Região Noroeste do Paraná. Bragantia, Campinas, v. 59, n. 1, p. 69-75, 2000.

WRIGHT, G. C.; SMITH, R. G.; MCWILLIAM, J. R. Differences between two grain sorghum genotypes in adaptation to drought stress: I., crop growth rate and yield response. Australian Journal of Agricultural Research, Canberra, v. 34, n. 6, p. 615-626, 1983. 